\section{E-LOGOS}

ELECTRONIC JOURNAL FOR PHILOSOPHY ISSN 1211-0442

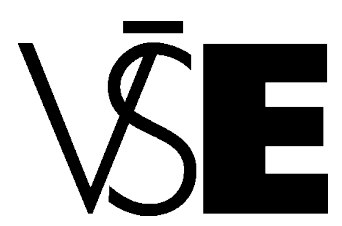

University of Economics

Prague

\title{
Přirozený zákon ve filosofii \\ 20. století a jeho zdroje
}

Miroslav Vacura

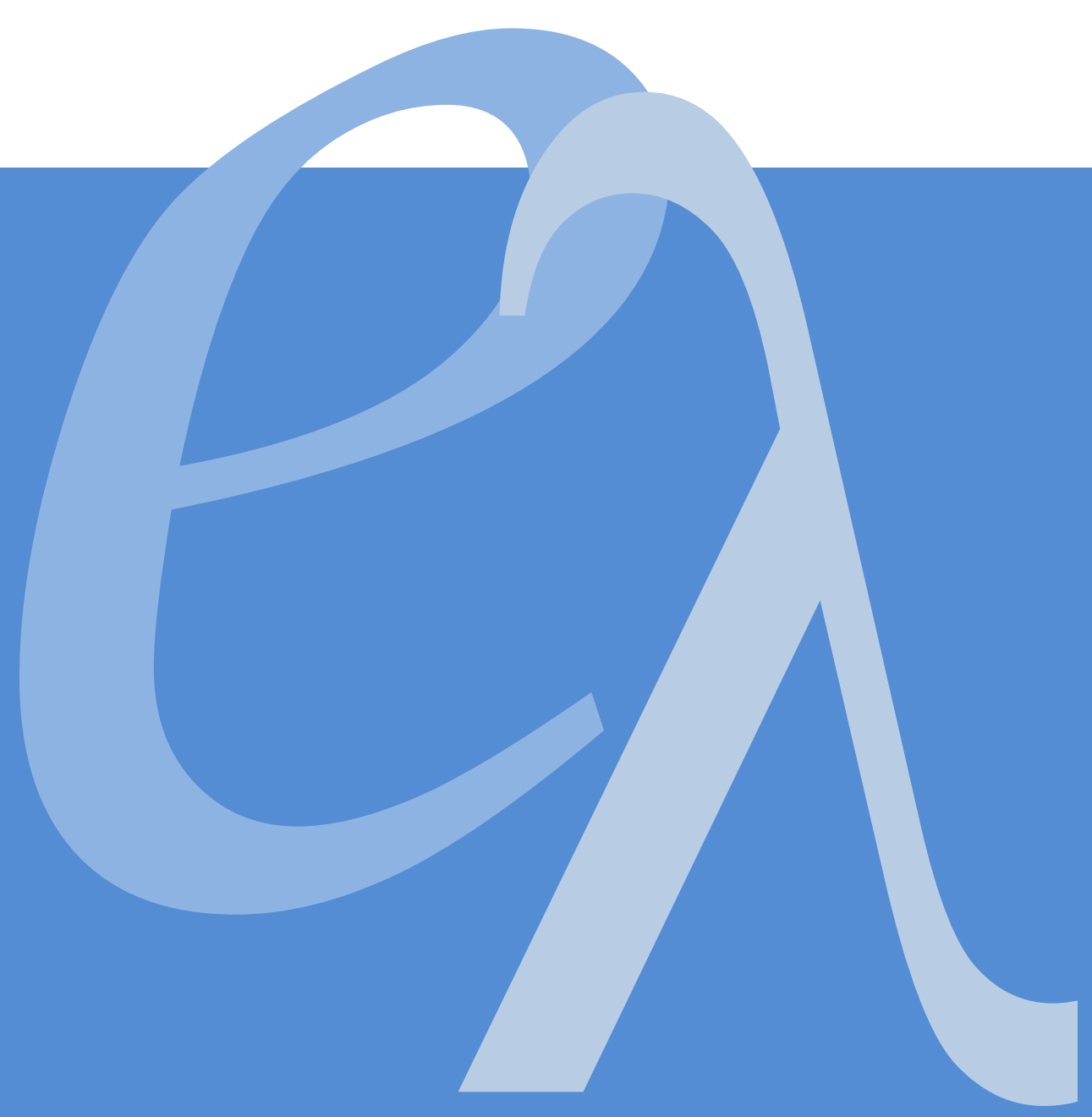




\begin{abstract}
Natural law is one of the most important ideas that form foundations of European philosophical, ethical and legal thought. Presented article provides exposition of development of idea of natural law in philosophical thought with emphasis on its key moments and textual explications of its most important theses that foreshadowed understanding of this concept in history. The purpose of this article is not detailed inquiry into one of the stages of its development or into thought of some of important authors, but to provide concise picture of its development as whole. The article starts with description of sources of natural law idea at pre-Socratic, following with Plato and Aristotle. The next part describes scholastic approach to natural law idea in works of T. Aquinas and Suarez. Then the focus of the article turns to Grotius, Pufendorf and Hobbes, and proceeds to short description theoretically opposite tradition of positivism represented by Bentham, Austin and their followers. The last part of text provides short description of natural law debate in works of the most important authors of twentieth century.
\end{abstract}

Keywords: natural law, law of nature, philosophy.

\title{
Abstrakt
}

Přirozený zákon je jednou z nejvýznamnějších idejí, která stojí v základech evropského filosofického, etického a právního myšlení. Předložený článek podává stručnou expozici vývoje ideje přirozeného zákona ve filosofickém myšlení s důrazem na jeho klíčové momenty a vyjádření nosných tezí, které předurčily rozumění tomuto pojmu v následujících obdobích. Jeho cílem není detailní probádání některé $\mathrm{z}$ jednotlivých etap či některého $\mathrm{z}$ autorů, ale naopak podat souhrnný a přehledný obraz vývoje této ideje. Východiskem je zde stručné načrtnutí hlavních zdrojů ideje přirozeného zákona $\mathrm{v}$ antice, počínaje předsokratiky, následně u Platóna a Aristotela a představením hlavních rysů stoické koncepce. Další část je věnovaná scholastickému uchopení problematiky přirozeného zákona u T. Akvinského a Suaréze. Následuje přiblížení novověkých úvah u Grotia, Pufendorfa a Hobbese. Tito teoretici jsou následně kontrastováni s průřezovým přehledem myšlení positivně právního u Benthama, Austina a jejich pokračovatelů, nebot' i vývoj positivistického myšlení výrazně přispěl k zformování moderní teorie přirozeného zákona, které stojí explicitně v opozici $\mathrm{k}$ němu. Text uzavírá přiblížení stavu přirozenoprávní diskuse $u$ nejvýznamnějších autorů 20. století.

Klíčová slova: přirozený zákon, filosofie. 
Téma přirozeného zákona (pokud pomineme oblast přírodní vědy, zejména fyziky a tedy „přrirodního zákona“) se týká v teoretické oblasti etiky, politické filosofie a filosofie práva. Této problematice je ve všech těchto oblastech věnována v současnosti značná badatelská pozornost. Na téma přirozeného zákona bylo jen $\mathrm{v}$ padesátých letech dvacátého století vydáno 282 knih, v šedesátých letech 486 knih, v sedmdesátých letech 493, v osmdesátých 557 a v devadesátých letech 694. ${ }^{1}$ Zároveň existuje řada odborných časopisů, které se věnují tomuto tématu. ${ }^{2}$

Také v oblasti politické se jedná o neobyčejně živou oblast. V řadě zemí existují strany "přirozeného zákona“ - například v USA, ${ }^{3}$ Kanadě, Velké Británii,, ${ }^{4}$ Izraeli, na Novém Zélandě v Pákistánu, stejně jako občanské organizace typu „Matky za přirozený zákon“. ${ }^{5} \mathrm{Na}$ pojem přirozeného zákona se také často odkazuje většina konzervativních stran, zejména katolicky orientovaných - katolická církev chápe pojem přirozeného zákona jako jeden ze základních pojmů svého etického systému a aplikuje jej i v oblastech politiky a práva.

V tomto kontextu považujeme za důležité prozkoumat a přiblížit historické ideové kořeny konceptu přirozeného zákona a základní směry jeho aplikace v současném filosofickém myšlení.

\section{Přirozený zákon jako filosofický koncept - historické kořeny}

Současná filosofie přirozeného zákona navazuje na dlouhou myšlenkovou tradici mající svůj počátek už v antice. V plném slova smyslu se pojem přirozeného zákona objevil sice až ve stoické filosofii, kořeny a původ tohoto konceptu můžeme ovšem sledovat až do starší filosofické tradice, která začíná u předsokratiků a pokračuje přes Platóna a Aristotela.

Z předsokratovských autorů jsou obvykle zmiňováni Anaximandros, Pythagoras, Hérakleitos, u nichž hraje roli vztah přírody a práva či zákona. Významné i jsou počiny dramatiků Aischyla (ve hře Eumenidés zkoumá podle přirozenosti správné tresty za vraždu, matkovraždu a cizoložství) a Sofokla (hra Král Oidipus tematizuje incest a otcovraždu a především pak hra Antigona, která obsahuje téma poslušnosti

\footnotetext{
${ }^{1}$ Kainz, H. P. Natural Law. An Introduction and Re-examination. Chicago and La Salle, Il.: Open Court, 2004, s. xiv.

${ }^{2}$ Za jiné jmenujme Natural Law Forum v současné době vycházející pod názvem American Journal of Jurisprudence.

${ }^{3}$ http:// www.natural-law.org/

${ }^{4}$ Některé ze stran „přirozeného zákona“ v USA, Kanadě a Velké Británii a v dalších zemích vycházely $\mathrm{z}$ učení guru Maharišiho Mahéše a jejich programem byla především „transcendentální meditace“. Ve Velké Británii tato strana působila v letech 1992 až 2001 (http://www.natural-law-party.org.uk/ ). Většina stran napojených na tuto skupinu ukončila svou činnost do roku 2004. Program této strany zahrnoval mj. i výcvik 1000 levitujících jogínů, kteří by svou duchovní silou byli schopni řešit světové společenské problémy. Toto pojetí přirozeného zákona nebude předmětem zkoumání $\mathrm{v}$ tomto textu.

5 V USA založena v roce 1996, organizace primárně bojující proti geneticky modifikovaným potravinám (http://www.safe-food.org/ )
} 
božských zákonů rodiny). Důležité jsou pak i Dějiny peloponéské války Sókratova současníka historika Thúkýdida (v nich zejména pak tzv. Mélský dialog). O božském zákonu píše i Hippias a Sókratův žák Xenofon, kontrastující nepsaný zákon, identifikovaný s přírodou, se zákony lidskými. ${ }^{6}$

U Platóna pak nacházíme diskusi přirozeného zákona zejména v dialogu Gorgias. Zde jeden z diskutujících - Kalliklés -, prezentuje pojetí přirozeného zákona v Thúkydidově duchu, totiž jako "zákon silnějšího“:

„Nebot' podle jakého práva vytáhl Xerxés proti Helladě nebo jeho otec proti Skythưm? A bylo by možno uvésti nesčíslně jiných takových př̀ikladů. Ale ti, myslím, dělají tyto věci podle přirozeného pojmu spravedlnosti $a$, bưh je svědek, podle přirozeného zákona, a ne snad podle toho, který si my dáváme; my utvář́me nejlepší a nejsilnější z nás samých, berouce je již z mládí jako lvíčata, a zaříkáváním a kouzelnými prostředky si je zotročujeme řikajíce, že je třeba zachovávati rovnost a v tom že záleži krásno i spravedlivo." 7

Proti Kalliklovu zákonu přírody, tedy zákonu silnějších, stojí lidské „umělé“ zákony. Další tematizaci podobné otázky pak najdeme i $\mathrm{v}$ Ústavěs a $\mathrm{v}$ jednom z pozdních Platónových textů, v dialogu Zákony, kde Platón explicitně vedle podobné relativizující teze, totiž že "nejoyšší právo jest to, cokoli si kdo vymáhá násilím", klade výklad o božském zákoně, který je nezávislý na psaném zákoně a je spojen se spravedlností, a ti kdo jej následují, jsou št'astni. ${ }^{10}$

Aristotelés o přirozeném zákonu mluví především ve své Rétorice:

"Zákonem nazývám jednak zákon zoláštní, jednak obecný, povšechný. Zvláštním jest ten, který si každé společenství zvlášt' pro sebe stanovilo, a to at' je nepsaný nebo psaný; obecným jest ten, jenž má základ v lidské přirozenosti. Nebot' jak asi každý tuší, jest přrirozené obecné právo a bezpráví $i$ tam, kde není vzájemného společenství, ani dohody,..."11

Při interpretaci tohoto Aristotelova výkladu je však třeba brát v úvahu celý smysl tohoto spisu, v15. kapitole první knihy se totiž ukazuje, že Aristotelés zde nevystupuje jako přesvědčený zastánce přirozeného (obecného) zákona, ale že ten je zde chápán jako argumentační prostředek k vítězství v soudním sporu.

Obecně lze napsat, že se ve starořecké filosofické tradici formují dvě hlavní myšlenková pojetí přirozeného zákona - jednak se jedná o přirozený zákon ve smyslu zákona př́rody v nás jakožto v našem živočišném základu, tedy ve smyslu „zákona silnějšího“ či principu sebezáchovy. Na druhé straně se formuje myšlenka

\footnotetext{
${ }^{6}$ Kainz, H. P. Natural Law. An Introduction and Re-examination. Chicago and La Salle, Il.: Open Court, 2004, s. 2.

7 Platón. Gorgias. Praha: OIKOUMENH, 2000, s. 483e. (Zvýraznění M. V.)

8 Platón. Ústava. Praha: OIKOYMENH, 2005, s. 444e.

${ }^{9}$ Platón. Zákony. Praha: OIKOUMENH, 1997, s. 890a.

10 Tamtéž, s. 715e.

${ }^{11}$ Aristotelés. Rétorika. Praha: Rezek, 2010, s. 1373b.
} 
přirozeného zákona $\mathrm{v}$ nás jakožto zákona božského, který je někdy spojován $\mathrm{s}$ rozumem $\mathrm{v}$ nás, $\mathrm{s}$ lidskou racionalitou.

Plné vyjádření zachycující všechny podstatné charakteristiky přirozeného zákona $\mathrm{v}$ druhém pojetí, jak byl pak rozvinut v následující tradici, můžeme najít u stoiků, konkrétně v Cicerově textu $O$ věcech veřejných:

"Je ale pravým zákonem zdravý rozum, který je ve shodě s př́rodou, rozlévající se ve všem, stálý věčný, který povolává k povinnosti rozkazy, zákazy odvrací od klamu, který však ani poctivým nerozkazuje nebo nezakazuje nadarmo, ani ničemy nepohne rozkazy či zákazy. Proti tomuto zákonu se není možno ohradit bez svatokrádeže, ani není dovoleno mu něco upř́t, ani ho nelze odmitnout jako celek, ani dokonce nemůžeme být zproštěni tohoto zákona senátem nebo lidem, ani nepotřebuje vykladače a interpreta Sexta Aelia, ani nebude jiný zákon v Ǩimě, jiný $v$ Athénách a jiný ted' a jiný později, nýbrž všechny národy a po všechny doby bude ovládat jeden věčný a neměnný zákon a jediný bude společný jako učitel a velitel všech: bůh. On je vynálezce tohoto zákona, jeho rozhodči a navrhovatel; ten, kdo neuposlechne, sám před sebou prchne a pohrdne lidskou prirozeností, bude už tím ohromně potrestán, byt́ i unikl všemu ostatnímu, co se považuje za trest." 12

Přirozený zákon je tak charakterizován jako: a) ve shodě s rozumem (je zde dokonce přímo identifikován s rozumem), b) ve shodě s prrírodou (je to zákon přírody), c) je to zákon morálně relevantní (zde souvisí s rozlišením poctivý/ničema), d) jednat proti němu je morálně nesprávné, e) nepodléhá lidské legislativě, ani vůli jednotlivců či hlasování, f) je srozumitelný prostému rozumu (nepotřebuje výklad právního specialisty), g) platí bez ohledu na místní zvyklosti jednotlivých kultur (platí všude), h) platil a bude platit po všechny doby (je věčný), i) je neměnný, j) jeho porušení samo v sobě zahrnuje trest (porušení je vykročením mimo lidskou přirozenost), h) původcem tohoto zákona je bůh. Každý tento bod takto uveden je samozřejmě jistým zjednodušením a vyžadoval by podrobnější výklad.

$\mathrm{Na}$ stoiu navazuje křest'anská filosofie, přičemž jedním z nejvýznamnějších impulsů pro začlenění koncepce přirozeného zákona do křest'anského myšlení byly následující řádky z Pavlova listu Římanům:

"Jestliže národy, které nemají zákon, samy od sebe činí to, co zákon žádá, pak jsou samy sobě zákonem, i když zákon nemají. Tím ukazuji, že to, co zákon požaduje, mají napsáno ve svém srdci, jak dosvědčuje jejich svědomi, poněvadž jejich myšlenky je jednou obviňují, jednou hájí."13

Nakolik byl Pavel z Tarsu reálně ovlivněn stoicismem (či převzal tyto myšlenky z jiných zdrojů) je předmětem rozsáhlých diskusí, nicméně už starověcí autoři

12 Cicero, M. T. O věcech veřejných. Praha: OIKOYMENH, 2009, s. 139 / std. 22 (33). (Uvádím nejprve číslo strany v českém překladu, následně za lomítkem dle standardní paginace).

${ }^{13}$ Řimanům 2:14-15 (ekumenický překlad). 
považovali tuto spojitost za fakt. Objevilo se dokonce několik podvržených listů mezi Pavlem a Senecou (jejichž smyslem bylo samozřejmě prokázat opačnou závislost, totiž že Seneca převzal své nejlepší myšlenky od křest'anských autorů). ${ }^{14}$

K plnému rozvinutí křest'anského pojetí ideje přirozeného zákona pak dochází ve středověké scholastické filosofii, jejíž vrchol představuje přirozenězákonní koncepce Tomáše Akvinského a Suaréze, která definuje základní rozvrh všech následujících křest’ansky orientovaných filosofických teorií přirozeného zákona. ${ }^{15}$

V základu přirozenězákonní filosofie u Tomáše Akvinského stojí koncept věčného zákona:

„A proto idea ř́zení věcí, která je v Bohu jako vládci vesmíru, má povahu zákona. Boží rozum ovšem nic nepoznává v čase, ale jeho poznání je věčné,... Proto je nutné nazvat onen zákon věčným." 16

Od tohoto věčného zákona je pak odvozen i přirozený zákon, protože všechny věci "na základě věčného zákona, který do nich byl vtištěn, maji sklon k vlastním úkonům a cílům. "17 Speciálně to platí i pro rozumné bytosti, a právě "účast rozumného tvora na věčném zákoně se nazývá prirozený zákon." 18 Vedle věčného a přirozeného zákona Tomáš Akvinský ještě definuje božský zákon - tj. zákon jak je člověku vyhlášený přímo Bohem v Písmu, a dále pak lidský zákon, což je ustanovení určené lidským rozumem, někdy vycházející z aplikace přirozeného zákona na konkrétní podmínky, někdy jako kodifikace principů, které jsou užitečné pro fungování lidského společenství. 19

Tomáš Akvinský pak konkretizuje přirozený zákon v několika bodech. Prvním principem přirozeného zákona je, že "dobro je nutno konat a o ně usilovat a zla je nutno se varovat" ${ }^{20}$ Jako dobro je pak poznáváno rozumem to, k čemu má člověk od své přirozenosti sklon. Přirozené sklony člověka pak mají několik úrovní, na té nejzákladnější, kterou má člověk společnou se všemi substancemi, je to sklon zachovat své vlastní bytí, sklon k sebezáchově. Za druhé, jako cosi společného se všemi živočichy, má člověk sklon ke spojení muže a ženy, k výchově dětí atd. Za třetí, a to je specifické pro člověka jako pro bytost nadanou rozumem, je v člověku sklon k poznávání a k životu ve společnosti. ${ }^{21}$

14 Grant, F. C. St. Paul and Stoicism. The Biblical World, Květen 1915, pp. 268-81.

${ }^{15} \mathrm{Srv}$. Lisska, A. J. Aquinas's theory of natural law: an analytic reconstruction. Oxford: Oxford University Press, 1998.

16 Tomáš Akvinský. Summa theologiae. I-II. Q91,a1. (Překlad uvádíme podle překladového výběru: Akvinský, T. Tomáš Akvinský o zákonech v Teologické sumě. Ed. Šprunk, K.. Praha: Krystal OP, 2003.)

17 Tamtéž, Q91,a2.

18 Tamtéž.

${ }^{19}$ Tamtéž, Q91,a3.

${ }^{20}$ Tamtéž, Q94,a2.

${ }^{21}$ Tamtéž. 
Suarézův výklad přirozeného zákona obsahuje jeho dílo De legibus, ac Deo legislatore (1612), ve kterém přichází se syntézou předchozích pozic a středověkých disputací, zejména mezi dominikány a jezuity. Podobně jako Tomáš Akvinský dělí Suaréz zákon na věčný, přirozený, božský positivní a lidský positivní. Oproti Tomášovi však Suaréz klade podstatně větší důraz na vůli zákonodárce jako předpoklad obligatornosti zákona a tak připravuje cestu pro pozdější právní positivismus. Věčný zákon je tak zákonem jen ve specifickém slova smyslu - jako zákon, který je božskou přirozeností, ${ }^{22 j e}$ to zákon, který uvaluje Bůh sám na sebe, ${ }^{23}$ je poznatelný jen tehdy, pokud se manifestuje $\mathrm{v}$ podobě některého $\mathrm{z}$ dalších tř́ typů zákona. ${ }^{24} \mathrm{Ve}$ striktním slova smyslu tedy $\mathrm{v}$ případě věčného zákona absentuje zákonodárce a jeho vůle, a jelikož přirozený zákon je způsob, jak je věčný zákon inherentní v morální přirozenosti člověka, tak totéž platí pro přirozený zákon:

„...neexistuje zákon ve vlastním smyslu slova s nařizujici silou, bez aktu vưle nějakého zákonodárce; avšak přirozený zákon nezávisí na vi̊li nějakého zákonodárce, tudiž není přesně řečeno zákonem... Je nepochybné, že Bưh je eficientní př́icinou a také učitelem přirozeného zákona. Ovšem z toho neplyne, že je zákonodárcem. Protože přirozený zákon nezahrnuje Boha jako zákonodárce, ale spiše ukazuje, co je dobré a špatné o sobě, stejně jako akt vidění směrovaný na daný objekt ukazuje, že je bílý nebo černý, a stejně jako výsledek Božího pusobení poukazuje na Boha jako autora, ale ne jako na zákonodárce. "25

Z přirozeného zákona (lidské přirozenosti) pak u Suaréze plyne, že lidé musí žít v určitých sociálních skupinách (rodina a nějaká vyšší struktura), které jsou organizovány s ohledem na společné dobro a zahrnují nějakou formu autority suveréna a legislativní moci, stejně jako nějaký systém vlastnických vztahů. Nicméně specifická povaha těchto uspořádání může být v různých společenstvích různá. ${ }^{26}$

V novověku pak přichází se svou reformulací přirozeného zákona Hugo Grotius, který bývá považován za významný mezník v dějinách přirozeného zákona, protože integruje tuto ideu do kontextu protestantského myšlení. Zatímco v současnosti považujeme vývoj od tomistického pojetí přirozeného zákona ke Grotiovi za v podstatě kontinuální, poměrně dlouho byly považovány tomistická a protestantská škola přirozeného zákona za podstatně odlišné. Hugo Grotius se přirozenému zákonu věnuje ve svém spise De iure belli ac pacis, zde se snaží jednotným zpo̊sobem vyložit dvě protikladné charakteristiky lidské přirozenosti, jednak prima naturæ, což jsou lidské instinkty a pudy směřující k sebezáchově, jednak lidský rozum (a pojetí

\footnotetext{
22 Suaréz, F. De legibus, ac Deo legislatore. Neapoli: Ex Typis Fibrenians, 1872, s. II.1.11.

23 Tamtéž, II.2.8.

24 Tamtéž, II.4.9.

25 Tamtéž, II.6.1-2.

26 Haakonssen, K. Natural Law and Moral Philosophy. From Grotius to the Scottish Enlightenment. Cambridge: Cambridge University Press, 1996, s. 17.
} 
toho, co je honestum), který umožňuje společný sociální život s druhými. ${ }^{27}$ Výsledná Grotiova teorie pak slouží k vyvrácení dvou hlavních teoretických protivníků skepticismu (Grotius zde explicitně odkazuje na tradici počínající Karneadem), a teologického voluntarismu. ${ }^{28}$

Dílo Samuela von Pufendorfa je luteránskou reakcí na Grotiovu filosofii. Pufendorf podobně jako Grotius má ambici budovat právní systém založený na přirozeném zákonu jakožto deduktivní systém po vzoru matematiky (eukleidovské geometrie). Ve svém spise Elementa tak představuje systém, který zahrnoval 21 definic, 2 axiomy a 5 pozorování. Ve svém nejvýznamnějším díle De iure pak na tomto základě, ale už bez zátěže formálního aparátu, vykládá svoji teorii přirozeného zákona. Lidská přirozenost je neměnná, stvořená Bohem a na jejím základě se konstituuje morální svět, který existuje paralelně se světem fyzickým, taktéž stvořeným Bohem. Lidská přirozenost zahrnuje potřebu sebezáchovy, základní sociabilitu (spojenou s poznáním, že sebezáchova není možná mimo společnost) a rozpoznání těchto charakteristik jako platných i pro druhé. Na tomto základě vzniká lidský jazyk jako médium, prostřednictvím kterého vznikají pravidla pro společný život a společenské instituce. ${ }^{29}$

Dalšími autory, kteří mluví o přirozeném zákonu, je pak Thomas Hobbes následovaný R. Cumberlandem a autory tzv. skotského osvícenství - Davidem Humem a Adamem Smithem. Hobbesovo pojetí navazuje na Grotiovo a explicitně formuluje vztah obou základních přirozenězákonních momentů. Na jedné straně je zde přirozené právo:

„Přirozené právo, které se v literatuře obyčejně nazývá jus naturale, je svoboda, kterou má každý člověk, aby uplatňoval svou vlastní moc, jak sám chce, $k$ zachování své vlastní prirozenosti, to znamená, svého vlastního života a tedy aby dělal cokoli, co pokládá podle svého vlastního úsudku a rozumu za nejohodnější prostředek $k$ tomuto cíli. “30

Toto přirozené právo pak v přirozeném stavu (tj. stavu, kdy neexistuje centrální vláda) je právem použití jakýchkoliv prostředků k zajištění své sebezáchovy a požitku, včetně zotročení či zabití jiných lidí. Toto právo pak má ve svých důsledcích (při realizaci) destruktivní účinky na lidský život, proto jeho následkem je, že náš rozum dospívá k určitým zásadám, které jsou implikovány principem sebezáchovy. Obecné vymezení přirozeného zákona je tudíž následující:

\footnotetext{
27 Tamtéž, s. 27.

${ }^{28}$ Grotius, H. De Iure Belli ac Pacis. Paris: Jean Barbeyrac, 1625, s. Prol.5.

29 Pufendorfova koncepce je tak z epistemologického hlediska předchůdcem odmítnutí vrozených idejí u J. Locka. Bůh sice vytváří základ našeho poznání tím, že nějakým konkrétním a neměnným způsobem konstituuje naši přirozenost, ovšem naše poznání pak už probíhá nezávisle, deduktivním způsobem založeným čistě na rozumu. ( Haakonssen, K. Natural Law and Moral Philosophy. From Grotius to the Scottish Enlightenment. Cambridge: Cambridge University Press, 1996, s. 38.

${ }^{30}$ Hobbes, T. Leviathan. Praha: OIKOYMENH, 2010.
} 
„Přirozený zákon (lex naturalis) je předpis nebo obecné pravidlo zprostředkované rozumem, podle něhož se člověku zakazuje dělat to, co může zničit jeho život nebo ho zbavit prostředků nezbytných pro zachování jeho života a opominout to, co by jej podle jeho domnění mohlo nejlépe zachovat." 31

Konkrétní specifikace těchto principů - přirozených zákonů - pak zahrnuje příkazy umožňující fungování organizovaného lidského společenství (státu), který by zaručoval zachovávání lidského života.

Vedle zmiňovaných britských autorů v čele s Hobbesem pak bývá mezi teoretiky spojené s filosofií přirozeného zákona řazen například i I. Kant. Takový pohled má i své kritiky, např́klad P. C. Westermanová tvrdí, že tito autoři jsou postavami spojenými s odklonem od filosofie přirozeného zákona $\mathrm{k}$ filosofii přirozených práv a tudíž řadit je do historie filosofie přirozeného zákona je striktně vzato nesprávné. Sama je tak ve své publikaci přeskakuje a na kapitolu věnovanou Pufendorfovi navazuje rovnou oddílem věnovaným autorovi, který podle ní obnovuje tradici filosofie přirozeného zákona ve 20. Století, J. Finnisovi. ${ }^{32}$ Westermanová tvrdí, že přestože za filosofa přirozeného zákona můžeme ve volném slova smyslu považovat kohokoli, kdo nějak spojuje moralitu s přírodou, bez ohledu na to jak, tak ona dává přednost tomu, používat tento výraz pouze pro autory, kteří se pokouší toto spojení založit na věčných nebo universálních principech. $Z$ jejího pohledu tak ani Kant ani Hume nevytvořili své normativní koncepce jakožto unifikované a založené na (lidské) přirozenosti, tudíž je není možné v tomto smyslu považovat za teoretiky přirozeného zákona. Hume sice vyšel z lidské přirozenosti, ovšem nikoli proto, aby zdůvodnil oprávněnost normativity lidského společenství, ale pouze proto, aby ji vysvětlil. ${ }^{33}$ Problémem Kantovy filosofie pak podle Westermanové je, že empirický svět je zde irelevantní vzhledem k morálnímu diskurzu. Empirické zákony přírody jsou u Kanta v protikladu k morálnímu zákonu, jehož zdrojem je na empirické přírodě nezávislý rozum. Sféra přírody je pro Kanta sférou žádostivosti, která je vzhledem k moralitě v lepším případě neutrální, v horším jde pak proti požadavkům mravního zákona. Westermanová tedy sice akceptuje Huma a Kanta jako (v oblasti filosofie přirozeného zákona) pokračovatele Pufendorfa, ovšem nikoli jako teoretiky přirozeného zákona $\mathrm{v}$ plném slova smyslu. ${ }^{34}$

Ačkoli některé body Westermanové interpretace filosofie přirozeného zákona $\mathrm{u}$ autorů skotského osvícenství (zejména D. Huma) a I. Kanta považujeme za možný námět na další polemickou diskusi, můžeme souhlasit s tím, že v 19. století zájem

\footnotetext{
${ }^{31}$ Tamtéž.

32 Westerman, P. C. The Disintegration of Natural Law Theory. Leiden, New York, Koln: Brill, 1997, s. 231.

33 Westerman, P. C. Hume and natural lawyers: a change of landscape. In: Hume and Hume's connexions. Ed. Stewart, M. A.; Wright, J. P. Edinburgh: Pennsylvania State University Press, 1994, pp. 83-104.

34 Westerman, P. C. The Disintegration of Natural Law Theory. Leiden, New York, Koln: Brill, 1997, s. 232-3.
} 
myslitelů o teorie spojené s myšlenkou přirozeného zákona postupně oslabuje a do centra pozornosti se postupně dostávají positivisticky orientované koncepce. Obnovení zájmu o přirozený zákon přichází až ve 20. století, po druhé světové válce.

\section{Positivistická právní škola}

Mezi zdroje positivistické právní filosofie někteří autoři řadí i výše jmenované filosofy Hobbese a Huma, zejména na základě konvecionalistické interpretace jejich politické filosofie. ${ }^{35}$ Plného rozvinutí však dosáhla positivistická právní filosofie teprve v díle Jeremyho Benthama. Betham ve svých textech věnovaných principům legislativy říká, že různé národy nazývaly své lokální zvyklosti týkající se rodinných vztahů přirozeným zákonem a vše, co těmto zvyklostem odporovalo, chápaly jako nečisté a hrozily se toho; ${ }^{36}$ dále že fráze jako "požadavek spravedlnosti“, ",správného rozumu“ nebo "přirozeného zákona“, byly používány pro přesvědčení lidí o pravdivosti nějakého morálního tvrzení tam, kde se mluvčí domníval, že není třeba nebo nedokáže toto tvrzení vysvětlit. ${ }^{37}$ Mnoho lidí tak podle Benthama mluví o přirozeném zákonu, ${ }^{38}$ ovšem používá odkazu na něj pouze jako způsobu jak zdůvodnit své osobní pocity (sentiments) ohledně toho, co je správné a co špatné. Tyto jejich pocity pak mají představovat řadu kapitol a oddílů přirozeného zákona. ${ }^{39}$ Původ používání pojmu přirozeného zákona pak vidí v označení skupiny zákonných pravidel regulujících lidské jednání, která však vznikla ještě před vznikem politické vlády a suveréna. ${ }^{40}$ Zákon jako takový definuje Bentham s čistě positivistickou ambicí jako „soubor znaků deklarujících vůli rozmyšlenou nebo prijatou suverénem“,41 přičemž důležité je zejména to, že tyto znaky (psané či vyřčené zákony) jsou „reálnými entitami,“ které jsou empiricky zaznamenatelné.

Na Benthamovu práci pak navazuje John Austin (1790-1859), britský filosof práva (nezaměňovat s filosofem jazyka jménem John Langshaw Austin žijícím ve 20. století), který tvrdil, že esenciální charakteristikou zákona je jeho schopnost

\footnotetext{
${ }^{35}$ Green, L. Legal Positivism. In: The Stanford Encyclopedia of Philosophy. Ed. Zalta, E. N. Stanford, CA: Stanford University, 2009.

${ }^{36}$ Bentham, J. Principles of the Civil Code. In: The Works of Jeremy Bentham Edinburgh: William Tait, 1843, I (p. 349).

${ }^{37}$ Bentham, J. A Fragment on Government. In: The Works of Jeremy Bentham Edinburgh: William Tait, 1843, I (p. XXXVIII).

38 Nebo o zákonu rozumu, správném rozumu (right reason), prrirozené spravedlnosti, přirozené poctivosty (natural ekvity), dobrém pořádku (good order), což má podle Benthama stejný účel, jako pojem přirozeného zákona.

39 Bentham, J. An Introduction to the Principles of Morals and Legislation. In: The Works of Jeremy Bentham Edinburgh: William Tait, 1843, I (pp. 8-9).

40 Bentham, J. Principles of Penal Law. In: The Works of Jeremy Bentham Edinburgh: William Tait, 1843, I (p. 453). Bentham ve svém odmítnutí konceptu přirozeného zákona také vycházel z odmítnutí vrozených idejí J. Lockem, inspiroval se však také myšlenkami F. Bacona a I. Newtona.

${ }^{41}$ Bentham, J. Of Laws. In: The Works of Jeremy Bentham Edinburgh: William Tait, 1843, I (p. 1). („,...an assemblage of signs declarative of volition conceived or adopted by the sovereign ina state...")
} 
vyžadovat poslušnost. Austin chtěl, aby systém zákonů svou jednoduchostí a určitostí byl podoben eukleidovskému geometrickému systému - nemůžeme zde nepřipomenout Spinozův pokus vybudovat celý filosofický systém more geometrico, kterým, jak ř́ká podtitul, byla jeho Etika - ovšem Austin by samozřejmě odmítnul jakékoli „metafyzické" př́edpoklady toho typu, s jakým pracuje Spinoza.

Základem Benthamovy a Austinovy koncepce je pojem suveréna, osoby nebo skupiny osob, které mají absolutní faktickou moc - ostatní občané státu poslouchají jejich př́kazy, suverén naopak neposlouchá př́kazy nikoho jiného. Zákony jsou pak specifickou podmnožinou př́ḱazů suveréna, jsou obecné, týkají se velkých skupin občanů a existuje hrozba sankcí za jejich neuposlechnutí. Základ tohoto pojetí zákona však najdeme už u Johna Locka, pro kterého je představa zákona, který by nebyl svázán se zákonodárcem s mocí prosazovat postihy za jeho př̀kročení, nemyslitelná:42

"Jelikož by bylo zcela marné předpokládat pravidlo předepsané svobodnému lidskému jednání, bez prípojení nějakého donucení, dobrého a zlého, k určení jeho vưle, musíme kdykoli předpokládám zákon, zároveñ predpokládat také nějakou odměnu nebo trest prípojený $k$ tomuto zákonu. Bylo by zcela marné, kdyby jedna inteligentní by tost vytvořila pravidlo pro jednání jiné, kdyby nemèla moc odměnit dodržování a potrestat porušování tohoto pravidla... Toto, jestli se nemýlím, je pravá přirozenost všech zákonủ, hodných svého jména..."

Tak tedy teorii práva chápeme jako positivistickou, protože právní systém je identifikován pouze s positivně (fakticky) existujícím systémem zákonů, a nepřipouští otázky týkající se práva suveréna na vydávání těchto př́kazů nebo morálnosti či prospěšnosti samotných zákonů. 43

Na tuto "austinovskou tezi“ pak v moderní době navazovaly další postavy filosofie práva, zejména H. L. A. Hart, Hans Kelsen, Alf Ross a Noberto Bobbio. Nederman charakterizuje positivistickou právní pozici následujícími body: ${ }^{44}$

1. Zákon představuje oblast zkoumání oddělenou od morální oblasti způsobem analogickým rozdílu mezi faktem a hodnotou.

2. Platnost zákona je „externi“ spíše než „interní“ v tom smyslu, že př́íkaz zákona, nikoli obsah samotného zákona, jej činí závazným.

3. Vyřešení všech otázek, které vyvstávají v souvislosti s př́kazy a požadavky zákona, je zcela empirickou záležitostí, jejíž vyřešení spadá do působnosti expertní znalosti praktikujících právníků.

\footnotetext{
42 Locke, J. Essay concerning human understanding. In: The Works of John Locke in Nine Volumes, 12th vyd. London: Rivington, $1824,1-2$ (p. II.xxviii.6).

${ }^{43}$ Green, L. Legal Positivism. In: The Stanford Encyclopedia of Philosophy. Ed. Zalta, E. N. Stanford, CA: Stanford University, 2009.

${ }^{44}$ Nederman, C. J. Introduction. In: Natural Law. An Introduction to Legal Philosophy New Brunswick and London: Transaction Publishers, 2009 (p. xi).
} 
4. Primární (pokud ne jedinou) úvahou ohledně toho, zdali má být příkaz uzákoněn, je jeho konzistence s předcházejícím legální rámcem.

Hans Kelsen (narozený v Praze) se snaží ve své Obecné teorii zákona a státu vytvořit právní filosofický systém (nazvaný ryzí nauka právní), který by nebyl zatížen politickými ideologiemi a moralizováním, což, jak se domníval, byl případ většiny systémů jeho doby (počátku 20. století), zároveň však odmítá redukcionistické snahy odvodit právní systém po vzoru př́rodních věd. V centru jeho teorie stojí idea hierarchie právních norem, v nichž ty nižší odvozují závaznost od vyšších. Na vrcholu této hierarchie pak stojí jediná základní norma (Grundnorm), jejíž závaznost už není odvozena od ničeho dalšího.

Aby závaznost této normy vysvětlil, Kelsen zavádí pojem „efektivnosti“, který v podstatě znamená, že normou se řídí relevantní část populace: „norma je považována za legálně platnou za podmínky, že patří do jistého systému norem, jistého řádu, který jako celek je efektivní“. ${ }^{45}$ Závaznost právní systému tak úzce souvisí s faktickou společenskou praxí. V průběhu života se však Kelsenovy názory postupně proměňovaly a od neokantovské pozice (jež zahrnovala i jistou formu odvození platnosti základní normy pomocí transcendentálního argumentu), která byla patrná $\mathrm{v}$ jeho prvních textech, se postupně dostává spíše do myšlenkového rámce humovského skepticismu, který je zřejmý v jeho Obecné teorii. ${ }^{46}$ Zde Kelsen chápe zákon jako specifickou sociální techniku, která „spočívá v dosažení požadovaného společenského jednání lidí, prostřednictvím hrozby použití donucovacích prostředků, v případě opačného jednání." 47 Jednotlivý zákon pak je chápán jako norma pro aplikaci těchto donucovacích prostředků a tako založený systém rozvrhuje do dvou rovin, označovaných jako "nomostatika" a „nomodynamika".

Další z positivisticky orientovaných teoretiků Joseph Raz vidí v určitých aspektech Kelsenovy koncepce analogii s přirozenězákonními teoriemi - jedná se zejména o jeho akceptaci toho, že normativita zákona má podobnou povahu jako normativita morální, či normativita náboženská. ${ }^{48}$ Raz sám chápe zákon jako soubor norem, které poskytují metodu či techniku určenou $\mathrm{k}$ autoritativnímu rozhodnutí sporů. Tyto normy jsou určeny a) pro „primární instituce“, b) pro jednotlivce. Tito jednotlivci jsou pak souzeni právě „primárními institucemi“, a právní stát se tak liší od jiných

\footnotetext{
${ }^{45}$ Kelsen, H. General Theory of Law and State. Cambridge, Mass.: Harvard University Press, 1945, s. 42. 46 Marmor, A. The Pure Theory of Law [online]. In: The Stanford Encyclopedia of Philosophy <http://plato.stanford.edu/entries/lawphil-theory/> [cit. 1 Leden 2012]

${ }^{47}$ Kelsen, H. General Theory of Law and State. Cambridge, Mass.: Harvard University Press, 1945, s. 19.

${ }^{48}$ Raz, J. Kelsen's Theory of the Basic Norm. In: The Authority of Law. Ed. Raz, J. Oxford: Oxford University Press, 1979.
} 
forem společenského uspořádání tím, že i primární instituce se musí řídit určitými normami (nikoli rozhodovat ad hoc) ${ }^{49}$

Další z autorů tradičně zařazovaných do positivistické tradice, H. L. A. Hart, ve své knize Pojem zákona sice argumentuje proti tradičnímu pojetí přirozeného práva, ovšem sám přichází s teorií minimálního obsahu přirozeného práva, který je tvořen pěti zjevnými pravdami, tzv. truismy.50 Těmito truismy pak jsou a) lidská zranitelnost, b) přibližná rovnost, c) omezený altruismus, d) omezené zdroje, e) omezené porozumění a síla vůle. ${ }^{51}$

Právní pozitivismus se tedy snaží oddělit morální soudy od právního systému, tudíž tradiční otázky filosofie práva (a politické filosofie), tedy otázky po ideálních nebo správných či spravedlivých zákonech, jsou eliminovány a do právního diskurzu vůbec nevstupují.

\section{Právní novotomismus}

Novotomistickou právní filosofii představují zejména Jacques Maritain (18821973) a Etienne Gilson (1884-1978). Jejím programem je návrat ke křestanské katolické filosofii, základním principem natura, id est Deus, velkým vzorem a základem učení pak filosofie Sv. Tomáše Akvinského, andělského doktora, učitele Církve. ${ }^{52}$

Zde je základem a garantem přirozeného zákona Bůh. Církev pak má privilegovanou roli vykladače tohoto zákona, který je přístupný rozumovému zkoumání, nikoli však zkoumání netrénované a neškolené mysli. Výklad přirozeného, tedy Božího, zákona je tak svěřen Církví pověřeným jednotlivcům patřičného vzdělání a schopností, ale taktéž duchovní průpravy, kteří pak mohou posuzovat a provádět kritiku navrhované či existující státní legislativy, co do jejího souladu s přirozeným zákonem. ${ }^{53}$

Rozvoj novotomistické právní filosofie přirozeného zákona byl podnícen chováním institucí a jednotlivců za druhé světové války, kdy zejména ve Francii byla

\footnotetext{
${ }^{49}$ Raz, J. Practical Reason and Norms. London: Hutchinson, 1975, s. 136-39. Srv. Finnis, J. Natural Law and Natural Rights. Oxford: Oxford University Press, 1980, s. 7.

${ }^{50}$ Pojem truismu je ve filosofii spojen především s tzv. filosofii zdravého rozumu G. E. Moora, který tak označoval samozřejmé nepopiratelné fakty každodenního života, se kterými musí být, podle jeho přesvědčení, každá smysluplná filosofická koncepce v souladu. Takovými truismy byly pro něj tvrzení jako "Země existovala mnoho let před tím, než jsem se narodil“, , "Jsem lidská bytost" , „Mé tělo existovalo včera." ( Moore, G. E. A Defense of Common Sense. Contemporary British Philosophy (2nd Series), 1925, 273-300.)

${ }^{51}$ Hart, H. L. A. Pojem zákona. překl. Fantys, P.. Praha: Prostor, 2004, s. 192-96.

52 Tomáš Akvinský byl v roce 1567 papežem Piem V. vyhlášen za učitele Církve, bývá též nazýván doctor angelicus - andělský doktor.

${ }^{53}$ Nederman, C. J. Introduction. In: Natural Law. An Introduction to Legal Philosophy New Brunswick and London: Transaction Publishers, 2009 (p. xiii).
} 
řada situací následně interpretována jako kolaborace, ovšem tyto případy byly v souladu s positivistickými právními př́istupy nebo jimi byly nepostižitelné. Novotomistická právní filosofie se tak rozvíjela zejména na poválečných francouzských akademických institucích, případně na některých místech severní Ameriky. ${ }^{54}$

V šedesátých letech dvacátého století pak zájem o novotomistické prrístupy k právu podnítila i encyklika papeže Pavla VI. Humanae Vitae, ve které se papež postavil proti umělým formám antikoncepce s odvoláním na tomistickou koncepci přirozeného zákona. Za papežovu pozici se postavili katoličtí filosofové Germain Grisez (*1929) a John Finnis (*1940). Grisez nejprve spolu s Johnem C. Fordem vydal významný článek věnovaný otázce vztahu neomylnosti v katolické církvi a antikoncepce. ${ }^{55}$ Finnis v reakci na další významný Grisezův článek ${ }^{56}$ vydal velmi vlivnou knihu Přirozený zákon a prirozená práva. ${ }^{57}$

Koncepce vymezená Finnisovou knihou je základem směru v oblasti filosofie práva, kterému se dnes říká „Nová teorie přirozeného zákona“ (Neww Natural-Law Theory). K této pozici se později připojili Robert George,58 Joseph Boyle; naopak někteři autoři, kteří se sami hlásili $\mathrm{k}$ tomistické tradici a teorii přirozeného zákona, tuto koncepci kritizovali - např́iklad Ralph McInerny,59 60 Henry Veatch ${ }^{61}$ a Russell Hittinger. ${ }^{62} \mathrm{Z}$ tohoto krátkého přehledu je patrné, proč je v současné době hlavně v oblasti filosofie práva problematika přirozeného zákona spojována především s novotomistickou katolickou filosofií. 63

John Finnis se ve výše zmíněné knize Přirozený zákon a přirozená práva snaží rehabilitovat teorii přirozeného zákona vycházející z učení Tomáše Akvinského, přičemž se domnívá, že jedním z hlavních problémů jsou její chybné reinterpretace (nebo desinterpretace) pozdějšími teoretiky přirozeného zákona. Zároveň si je

\footnotetext{
54 Tamtéž, s. xiv.

55 Teologické pozadí debaty popisuje článek: Grisez, G.; Ford, J. Contraception and the Infallibility of the Ordinary Magisterium. Theological Studies, Červen 1978.

56 Grisez, G. The First Principle of Practical Reason: Commentary on the Summa theologiae, 1-2, Question 94, Article 2. Natural Law Forum, 1965. (Všimněme si zde narážky na kategorický imperativ, který je Kantem vykládán jako apriorní morální princip praktického rozumu).

57 Finnis, J. Natural Law and Natural Rights. Oxford: Oxford University Press, 1980.

58 George, R. In Defense of Natural Law. Oxford: Oxford University Press, 1999.

59 McInerny, R. Ethica Thomistica: The Moral Philosophy of Thomas Aquinas. Washington, D.C.: Catholic University of America Press, 1982.

60 McInerny, R. Aquinas on Human Action: a Theory of Practice. Washington, D.C.: Catholic University of America Press, 1992.

61 Veatch, H. Swimming Against the Current in Contemporary Philosophy. Washington, D.C.: Catholic University of America Press, 1990.

${ }^{62}$ Hittinger, R. A Critique of the New Natural Law Theory. Notre Dame: Notre Dame University Press, 1987.

${ }^{63}$ Kainz, H. P. Natural Law. An Introduction and Re-examination. Chicago and La Salle, Il.: Open Court, 2004, s. xiv.
} 
vědom, že hlavním argumentem proti přirozenězákonním teoriím je humovské rozlišení mezi „je“ a "má být“, proto mu věnuje ve svém textu velkou pozornost. Následně pak o kapitolách tvořících druhou část jeho knihy a podávajících výklad jeho naturalistické koncepce ř́ká:

"tyto dvě kapitoly se zabývají evaluativním substrátem všech morálních soudů. To znamená, že se zabývaji akty praktického rozumu, v nichž uchopujeme základní hodnoty lidské existence a tudíz i základní principy praktického uvažování."64

Finnis následně vymezuje sedm forem dobra, pod něž je možné ostatní podřadit: a) život, b) vědění, c) hra, d) estetická zkušenost, e) společenskost (přátelství), f) praktická rozumnost, g) náboženství a nejobecnější „filosofické“ otázky týkající se našeho života a světa. Finnis přitom tyto základní formy dobra považuje za o sobě evidentní. ${ }^{5}$ Přestože je tato jeho pozice inspirována a v mnoha ohledech blízká koncepci přirozeného zákona u Tomáše Akvinského, je zde podstatný rozdíl. Zatímco Tomáš zřejmě ve své koncepci odvozuje přirozený zákon z inklinací daných v lidské přirozenosti, Finnis toto odmítá - jako součást své obrany proti humovskému problému odvození normativity z faktů. Evidence základních forem dobra tak u něj není evidencí jejich odvození, ale evidencí svou formou stejnou jakou se vyznačují základní geometrické axiomy.

Tato Finnisova strategie je však také podrobena kritice. Např. P. Westermanová se ve své historické studii Rozpad teorie prirozeného zákona: Od Akvinského po Finnise66 snaží na základě důkladného prozkoumání prací Suaréze, Grotia a Pufendorfa ukázat, že se nejednalo o desinterpretace teorie Tomáše Akvinského, ale o snahu o vyřešení problémů inherentních $\mathrm{v}$ Tomášově pozici. Ústup přirozeně zákonních teorií pak byl důsledkem toho, že tyto pokusy o vyřešení vnitřních rozporů teorií přirozeného zákona byly neúspěšné. Zároveň se pak snaží ukázat, že John Finnis ve svém výkladu nakonec dochází do stejných problémů a vnitřních rozporů, které se nepodařilo vyřešit jeho předchůdcům a ani u něj nejsou uspokojivě dořešeny.

Na výše zmíněnou práci H. L. A. Harta Pojem zákona reagují Lon Fuller několika články a knihou Morálka práva ${ }^{67}$ a Ronald Dworkin spisem Když se práva berou vážně.68 Oba dva se domnívají, že je třeba jít za Hartův minimální obsah a hájí nutnost určité formy přirozeného zákona. Fuller přichází s myšlenkou (přirozeného zákona) „udržení komunikace“ v oblasti legislativy, který se týká osmi typů selhání, proti nimž by mělo být postupováno: a) selhání charakteru zákona jako pravidla, jehož důsledkem je ad hoc rozhodování, b) selhání zveřejnění zákonných norem, c) selhání ve formě retroaktivní aplikace zákona, d) selhání srozumitelnosti, v jehož důsledku

\footnotetext{
64 Finnis, J. Natural Law and Natural Rights. Oxford: Oxford University Press, 1980, s. 59.

65 Tamtéž, str. 85-89.

${ }^{66}$ Westerman, P. C. The Disintegration of Natural Law Theory. Leiden, New York, Koln: Brill, 1997.

${ }^{67}$ Fuller, L. L. Morálka práva. Praha: OIKOYMENH, 1998.

${ }^{68}$ Dworkin, R. M. Když se práva berou vážně. Praha: OIKOYMENH, 2001.
} 
nejsou normy pro populaci srozumitelné, e) selhání přijetím kontradiktorních norem, f) selhaní ve formě požadavků (na znalosti), kterým nemůže dotčená strana dostát, g) selhání ve formě př́liš častých změn zákona, h) selhání ve formě nesouladu mezi zákonem a způsobem jeho aplikace. Obecně jsou však tyto principy považovány za přiliš technické a týkající se teoretických otázek jurisprudence a nesouvisející přímo s přirozeným zákonem v obecném, tradičním chápání. ${ }^{69}$

Přibližně od padesátých let dvacátého století dochází k renesanci zájmu o koncepce přirozeného zákona i v oblasti etiky. Zatímco v oblasti právní filosofie se jednalo o potřebu najít teoretický koncept zakládající postupy Norimberského procesu, v oblasti etiky tato nově zaměřená pozornost souvisela s obnovením zájmu o Aristotelovu morální filosofii.

Za významný je v tomto ohledu považován článek Elizabeth Anscombe Moderní morální filosofie, ${ }^{70}$ ve kterém autorka upozorňuje na to, že moderní etika zcela ztratila ze zřetele morální psychologii; teorii povinnosti je tedy třeba revidovat a zároveň je třeba věnovat pozornost typicky aristotelským morálním konceptům jako ctnost, praktický rozum, získané dispozice apod. S obnovou zájmu o Aristotelovu etiku pak také přichází obnovený zájem o morální koncepce Sv. Tomáše Akvinského, u něhož, jak jsme viděli, nacházíme významný zdroj současného rozvinutí teorií přirozeného zákona. ${ }^{71}$ Za další takto významný text v oblasti současné morální filosofie pak lze považovat Ztrátu ctnosti A. MacInryra. Opět zde nalézáme kritiku vývoje morální filosofie od osvícenství a snahu o návrat k etice aristotelské tradice.

\section{Závěrem}

V tomto poměrně stručném a zahuštěném článku jsme se pokusili naznačit v historickém průřezu základní momenty vývoje ideje přirozeného zákona, od počátků u předsokratiků a filosofů klasického období - Platóna a Aristotela, následně u stoických filosofů a poté u autorů vrcholného středověku - Tomáše Akvinského a Suaréze, kteří do značné míry předurčili její další vývoj. Z autorů novověkých jsme se zmínili především o Hobbesovi a Grotiovi a Pufendorfovi. Výklad pak doplnil krátký oddíl věnovaný positivistické koncepci zákona, která stojí $\mathrm{k}$ přirozenězákonním koncepcím $\mathrm{v}$ opozici. Závěr textu pak byl zaměřen na současné autory, především pak na Finnise, který představuje centrální postavu obnoveného zájmu o ideu přirozeného zákona ve filosofii. Mnoho autorů a textů jsme jen zmínili a do budoucna tak zůstává závazek vyrovnat tento dluh důkladnějším a

\footnotetext{
${ }^{69}$ Kenneth, E. Functionalism and Legal Theory: the Hart-Fuller Debate Revisited. De philosophia, 1998 (pp. 213-32). ; Srv. Kainz, H. P. Natural Law. An Introduction and Re-examination. Chicago and La Salle, Il.: Open Court, 2004, s. 45.

${ }^{70}$ Anscombe, E. Modern Moral Philosophy. Philosophy, Leden 1958.

${ }^{71}$ Lisska, A. J. Aquinas's theory of natural law: an analytic reconstruction. Oxford: Oxford University Press, 1998, s. 2.
} 
rozvinutějším textem. Tato poznámka se týká zejména navázání na tradici přirozeného zákona a přirozenosti v současné etice, kterou jsme mohli pouze zmínit na závěr celého textu. 


\section{Bibliografie}

AKVINSKý, T. Tomáš Akvinský o zákonech v Teologické sumě. Ed. Šprunk, K.. Praha: Krystal OP, 2003.

ANSCOMBE, E., Modern Moral Philosophy. Philosophy. Leden 1958.

ARISTOTELÉS. Rétorika. Praha: Rezek, 2010.

BENTHAM, J. A Fragment on Government. In: The Works of Jeremy Bentham Edinburgh: William Tait, 1843, I.

BENTHAM, J. An Introduction to the Principles of Morals and Legislation. In: The Works of Jeremy Bentham Edinburgh: William Tait, 1843, I.

BENTHAM, J. Of Laws. In: The Works of Jeremy Bentham Edinburgh: William Tait, 1843 , I.

BENTHAM, J. Principles of Penal Law. In: The Works of Jeremy Bentham Edinburgh: William Tait, 1843, I.

BENTHAM, J. Principles of the Civil Code. In: The Works of Jeremy Bentham Edinburgh: William Tait, 1843, I.

CICERO, M. T. O věcech veřejných. Praha: OIKOYMENH, 2009.

DWORKIN, R. M. Když se práva berou vážně. Praha: OIKOYMENH, 2001.

FINNIS, J. Natural Law and Natural Rights. Oxford: Oxford University Press, 1980.

FULLER, L. L. Morálka práva. Praha: OIKOYMENH, 1998.

GEORGE, R. In Defense of Natural Law. Oxford: Oxford University Press, 1999.

GRANT, F. C., St. Paul and Stoicism. The Biblical World. Květen 1915. pp. 268-81.

GREEN, L. Legal Positivism. In: The Stanford Encyclopedia of Philosophy. Ed. Zalta, E. N. Stanford, CA: Stanford University, 2009.

GRISEZ, G., The First Principle of Practical Reason: Commentary on the Summa theologiae, 1-2, Question 94, Article 2. Natural Law Forum. 1965.

GRISEZ, G.; FORD, J., Contraception and the Infallibility of the Ordinary Magisterium. Theological Studies. Červen 1978.

GROTIUS, H. De Iure Belli ac Pacis. Paris: Jean Barbeyrac, 1625. 
HAAKONSSEN, K. Natural Law and Moral Philosophy. From Grotius to the Scottish Enlightenment. Cambridge: Cambridge University Press, 1996.

HART, H. L. A. Pojem zákona. Překl. Fantys, P.. Praha: Prostor, 2004.

HITTINGER, R. A Critique of the New Natural Law Theory. Notre Dame: Notre Dame University Press, 1987.

HOBBES, T. Leviathan. Praha: OIKOYMENH, 2010.

KAINZ, H. P. Natural Law. An Introduction and Re-examination. Chicago and La Salle, Il.: Open Court, 2004.

KELSEN, H. General Theory of Law and State. Cambridge, Mass.: Harvard University Press, 1945.

KENNETH, E., Functionalism and Legal Theory: the Hart-Fuller Debate Revisited. De philosophia. 1998.

LISSKA, A. J. Aquinas's theory of natural law: an analytic reconstruction. Oxford: Oxford University Press, 1998.

LOCKE, J. Essay concerning human understanding. In: The Works of John Locke in Nine Volumes. 12th vyd. London: Rivington, 1824 , 1-2.

MARMOR, A. The Pure Theory of Law [online]. In: The Stanford Encyclopedia of Philosophy <http://plato.stanford.edu/entries/lawphil-theory/> [cit. 1 Leden 2012]

MCINERNY, R. Ethica Thomistica: The Moral Philosophy of Thomas Aquinas. Washington, D.C.: Catholic University of America Press, 1982.

MCINERNY, R. Aquinas on Human Action: a Theory of Practice. Washington, D.C.: Catholic University of America Press, 1992.

MOORE, G. E. 'A Defense of Common Sense'. Contemporary British Philosophy (2nd Series), 1925, 273-300.

NEDERMAN, C. J. Introduction. In: Natural Law. An Introduction to Legal Philosophy New Brunswick and London: Transaction Publishers, 2009.

PLATÓN. Zákony. Praha: OIKOUMENH, 1997.

PLATÓN. Gorgias. Praha: OIKOUMENH, 2000. 
PLATÓN. Ústava. Praha: OIKOYMENH, 2005.

RAZ, J. Practical Reason and Norms. London: Hutchinson, 1975.

RAZ, J. Kelsen's Theory of the Basic Norm. In: The Authority of Law. Ed. Raz, J. Oxford: Oxford University Press, 1979.

SUARÉZ, F. De legibus, ac Deo legislatore. Neapoli: Ex Typis Fibrenians, 1872.

VEATCH, H. Swimming Against the Current in Contemporary Philosophy. Washington, D.C.: Catholic University of America Press, 1990.

WESTERMAN, P. C. Hume and natural lawyers: a change of landscape. In: Hume and Hume's connexions. Ed. Stewart, M. A.; Wright, J. P. Edinburgh: Pennsylvania State University Press, 1994, pp. 83-104.

WESTERMAN, P. C. The Disintegration of Natural Law Theory. Leiden, New York, Koln: Brill, 1997. 


\section{E-LOGOS}

ELECTRONIC JOURNAL FOR PHILOSOPHY

Ročník/Year: 2011 (vychází průběžně/ published continuously)

Místo vydání/Place of edition: Praha

ISSN 1211-0442

Vydává/Publisher:

Vysoká škola ekonomická v Praze / University of Economics, Prague

nám. W. Churchilla 4

Czech Republic

13067 Praha 3

IČ: 61384399

Web: $\underline{\text { http://e-logos.vse.cz }}$

Redakce a technické informace/Editorial staff and technical information:

Miroslav Vacura

vacuram@vse.cz

Redakční rada/Board of editors:

Ladislav Benyovszky (FHS UK Praha, Czech Republic)

Ivan Blecha (FF UP Olomouc, Czech Republic)

Martin Hemelík (VŠP Jihlava, Czech Republic)

Angelo Marocco (Pontifical Athenaeum Regina Apostolorum, Rome, Italy)

Jozef Kelemen (FPF SU Opava, Czech Republic)

Daniel Kroupa (ZU Plzeň, Czech Republic)

Vladimír Kvasnička (FIIT STU Bratislava, Slovak Republic)

Jaroslav Novotný (FHS UK Praha, Czech Republic)

Jakub Novotný (VŠP Jihlava, Czech Republic)

Ján Pavlík (editor-in-chief) (VŠE Praha, Czech Republic)

Karel Pstružina (VŠE Praha, Czech Republic)

Miroslav Vacura (executive editor) (VŠE Praha, Czech Republic) 